\title{
TEMPORAL VARIATION OF THE TOTAL PHENOLIC COMPOUNDS CONCENTRATION IN Vochysia divergens Pohl. (VOCHYSIACEAE) LEAVES IN THE BRAZILIAN PANTANAL ${ }^{1}$
}

\author{
Deise Martins Uriu², Bruna Serpa de Almeida Godoy ${ }^{3}$, Leandro Dênis Battirola ${ }^{4}$, Carla Regina \\ Andrighetti ${ }^{5}$, Marinêz Isaac Marques ${ }^{6}$ and Denia Mendes de Sousa Valladao ${ }^{*}$
}

\footnotetext{
${ }^{1}$ Received on 15.09.2015 accepted for publication on 28.06.2017.

${ }^{2}$ Universidade Federal de Mato Grosso, Mestrado em Ciências Ambientais, Mato Grosso, Brasil. E-mail: <deisehand@gmail.com>.

${ }^{3}$ Universidade Federal de Mato Grosso, Programa de Pós-Graduação em Ciências Ambientais, Mato Grosso, Brasil. E-mail: <bruuh.godoy@hotmail.com>.

${ }^{4}$ Universidade Federal de Mato Grosso, Doutorado em Ciências Biológicas, Mato Grosso, Brasil. E-mail: $<$ Idbattirola@uol.com.br $>$. ${ }^{5}$ Universidade Federal de Mato Grosso, Instituto de Ciências da Saúde,Sinop, Mato Grosso, Brasil. E-mail: <crandrei20@yahoo.com.br> and $<$ deniavalladao@gmail.com>.

${ }^{6}$ Universidade Federal de Mato Grosso, Departamento de Biologia e Zoologia, Cuiabá, Mato Grosso, Brasil. E-mail: $<$ marinez513@gmail.com>.

*Corresponding author.
}

\begin{abstract}
The total phenol concentration present in Vochysia divergens Pohl. (Vochysiaceae) leaves in the Pantanal was analyzed. Work was carried out between September/2012 and June/2013 which is made up by the dry season (September/2012), the beginning of the rising water (December/2012), the high water (March/2013) followed by the receding water period (June/2013). For the purpose of the research fifteen trees were selected, five from each sample area. The phenolic content in the leaves was obtained from the samples which were dried, steeped with ethanol: water and centrifuged. The extract was used to determine the concentration of total phenols using the Folin-Ciocalteu spectrometric method. There was no difference among the sampling areas; however the values were different in relation to seasonal periods. The lowest concentration was recorded in the dry season (young leaves) increasing gradually at the beginning of the rising water, with higher levels at the end of high water and receding water season. The highest concentration of phenols occurred during the receding water period (end of the life cycle of $V$. divergens leaves), followed by high and rising water periods. The increase in phenol concentration is associated with the Pantanal flood cycle, and related to the phenology of the $V$. divergens leaves.
\end{abstract}

Keywords: Phenols; Phenology; Seasonality; Vochysiaceae.

\section{VARIAÇÃO TEMPORAL DA CONCENTRAÇÃO DE COMPOSTOS FENÓLICOS TOTAIS EM FOLHAS DE Vochysia divergens Pohl. (VOCHYSIACEAE) NO PANTANAL BRASILEIRO}

\begin{abstract}
RESUMO - Analisou-se a concentração de fenóis totais presentes nas folhas de Vochysia divergens Pohl. (Vochysiaceae) na região norte do Pantanal, coletadas entre setembro de 2012 e junho de 2013, compreendendo o período de seca (setembro/2012), o começo do período de inundação (dezembro/2012), período de cheia (março/2013) seguido pela vazante (junho/2013). Para a coleta foram selecionadas 15 árvores, cinco em cada área amostral. A concentração de fenóis nas folhas foi obtida com as amostras secas à $40^{\circ} \mathrm{C}$, maceradas com etanol: água e centrifugada. O extrato foi usado para determinação da concentração de fenóis totais utilizando-se o método espectrométrico de Folin-Ciocalteu. Não houve diferença entre as áreas amostrais, entretanto os valores foram diferentes em relação aos períodos sazonais. A menor concentração foi registrada no período da seca (folhas jovens) aumentando gradativamente no início do período de enchente com maiores niveis no final do período de inundação. A maior concentração de fenóis ocorreu durante a vazante (final
\end{abstract}


do ciclo de vida das folhas de $\boldsymbol{V}$. divergens), seguida pela cheia e enchente. O aumento na concentração de fenóis, provavelmente, está associado ao ciclo de inundações do Pantanal, e relacionado com a fenologia das folhas de V. divergens.

Palavras-Chave: Fenóis; Fenologia; Sazonalidade; Vochysiaceae.

\section{INTRODUCTION}

Phenolic compounds are substances which have at least one aromatic ring with one or more hydroxyl substituents, including their functional groups (Simões et al., 2007). Various different phenolic compounds, mainly flavonoids, phenolic acids, simple phenols, coumarins, tannins, and tocopherols are known (Shahidi and Naczk, 1995; Angelo and Jorge, 2007; Simões et al., 2007). These compounds have enormous structural and functional diversity (Hagerman and Butler, 1991), many of which are functionally unknown while others appear to be simple intermediates of the normal metabolism of the plants (Backman, 2000).

Due to their variable structures phenols perform different functions in plants (Hagerman and Butler, 1991). Some are synthesized in response to a physical injury such as infection (bacteria, fungus, nematode or virus), or any other kind of stress, be it nutritional, water or pruning (Nicholson and Hammerschimidt, 1992). They are also used as a chemical defense mechanism of plants, acting as a deterrent to herbivores, creating resistance to pathogens, and thus interfering in insectplant interaction, as they can act as allomones or kairomones depending on the allelochemical used during the interaction process (Pizzamiglio-Gutierez, 2009).

The qualitative and quantitative analysis of total phenolic compounds can be determined by various methods such as thin layer chromatography and high performance liquid chromatography (Simões et al., 2007). However, the spectrophotometric analysis is the most used (Roginsky and Lissi, 2005; Sousa et al., 2007), with the Folin-Ciocalteu reagent (Albuquerque et al., 2005).

Knowledge of the phenolic compounds synthesized by a plant is essential for the understanding of the ecological interaction processes, bearing in mind that they are secondary metabolites and act as chemical defense mechanism (Pizzamiglio-Gutierez, 2009). According to Pinto et al. (2002), the plant kingdom is that which has contributed in the most significantly manner to the supply of secondary metabolites, many of which, are of great value due to their applications as medicines, cosmetics, food and agrochemicals. Studies on the chemical profile of plants contribute to a better understanding of the functioning of an ecosystem, as well as the identification of substances that may have commercial and industrial interest (Pinto et al., 2002; Pizzamiglio-Gutierez, 2009).

Few vegetable species of the Brazilian Pantanal have been evaluated with respect to their chemical composition. Chaibub et al. (2013) analyzed the essential oil Spiranthera odoratissima A. St.-Hil (Rutaceae) and registered its compounds â-caryophyllene, ã-muurolene, bicyclogermacrene e ä-cadinene; Cobianchi et al. (2013) while using Combretum lanceolatum Pohl. (Combretaceae) flowers identified such flavonoids as dillenetin, isorhamnetin, quercetinand quercetin3-Ometil in the chemical composition of this species. Trevisan et al. (2008) isolated alkaloids in the bark of the roots of Acosmium dasycarpum (Vog.) Yakovlev (Fabaceae). The knowledge and identification of compounds synthesized by plant species which are widely distributed in the Pantanal is fundamental for the understanding of its physiological processes generators as well as their relations with the seasonal variations of this ecosystem.

The Vochysia divergens Pohl. (Vochysiaceae) is one of the main tree species in the northern Pantanal region (Silva et al., 2000; Nunes-da-Cunha and Junk, 2011), identified as an evergreen, pioneer and a floodadapted plant in this ecosystem (Pott and Pott, 1994). Little is known about the chemical composition and ecophysiological mecanisms of this species and its applications. It is considered as a weed or invader in fields and native grasslands causing problems for local ranchers (Nunes-da-Cunha and Junk, 2004; Santos et al., 2006), due to its plasticity and tolerance in relation to different intensities of flooding and light in the colonization of these areas (Dalmolin et al., 2012). Vochysia divergens has a strong physiological adaptation to flooded environment, with variations in its phenology according to the temporal fluctuation of the water level (Nunes-da-Cunha and Junk, 2000, 2004; Dalmagro et al., 2013; Damolin et al., 2015). Although this adaptation interfering with the dynamics of the local ecosystem

Revista Árvore. 2017;41(3):e410316

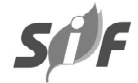


through the ecological interactions it has with different taxonomic groups (Marques et al., 2001, 2006, 2014; Arieira and Nunes-Da-Cunha, 2006).

Thus, considering the close association between the phenology of $V$. divergens and water seasonality of the Pantanal, mainly in relation to periodic flooding, as well as the importance of chemical studies of their components to understand interactions with the environment and other species, this study aimed to analyze (i) the temporal variation in the total concentration of phenolic compounds present in the leaves of $V$. divergens in different phenologic stages, associated with different seasonal periods of the Pantanal of Mato Grosso, (ii) as well as the variation of this concentration between areas subject to different flooding intensities in this region.

\section{MATERIALAND METHODS}

\section{STUDYAREA}

This study was carried out in the Cuiabá-Bento Gomes-Paraguaizinho Pantanal, called Pantanal de Poconé (Adámoli, 1982), between the river Bento Gomes (16 $18^{\prime} 55.01 " \mathrm{~S}$ and 56 32’33.64"W) and the Advanced Pantanal Research Base (BAPP) (16 $30^{\circ} 3.41^{\prime \prime S}$ and $\left.56^{\circ} 24^{\prime} 47.76^{\prime \prime} \mathrm{W}\right)$ of the Federal University of Mato Grosso, located on the SESC Pantanal property near the river Cuiabá (Figure 1). The climate in the region is of tropical Savannah type, the Aw type according to the Köppen Climate Classification, characterized by dry winters and rainy summers, with temperatures ranging from between $22^{\circ} \mathrm{C}$ and $32^{\circ} \mathrm{C}$ (Hasenack et al., 2003). Annual rainfall varies between 1,000 and $1,500 \mathrm{~mm}$ (Junk et al., 2006). The seasonality of the region is determined by four periods (dry season, rising water, high water and receding water season) which define the alteration between terrestrial and aquatic phases of the ecosystem (Heckman, 1998).

\section{SAMPLEDESIGN}

In this locality three sampling areas (A1, A2 and A3) were delimited and categorized by different degree of flooding to which they are subject, as well as the distinct environmental characteristics (Figure 1). The three areas are independent and are distributed over a course of $20 \mathrm{~km}$, with the distance between A1 and A2 being $12 \mathrm{~km}$, between $\mathrm{A} 2$ and $\mathrm{A} 38 \mathrm{~km}$ and, between $\mathrm{A} 1$ and A3 20km. Area 1 (A1)(56²5'51.70"W and 16²4’37.50"S) is characterized by being the most elevated or highest area, formed by a plateau with savanna vegetation and predominantly sandy soil, which is less impacted by periodic flooding $(0.1 \mathrm{~m}$ average amplitude). Area 2 (A2)(56 $24^{\prime} 7.98^{\prime \prime} \mathrm{W}$ and $\left.16^{\circ} 27^{\prime} 25.31^{\prime \prime} \mathrm{S}\right)$ is considered intermediate, with vegetation that consists of dry forest and transitional forest areas with cerrado and silty sandy soil with average flooding $(0.25 \mathrm{~m}$ average amplitude). The third area (A3) (56 $25^{\circ} 25.05^{\prime \prime} \mathrm{W}$ and $\left.16^{\circ} 29^{\prime} 11.18^{\prime \prime S}\right)$, located near the river Cuiabá, remains flooded for a longer period compared to the other two areas, in addition to receiving the highest flood level ( $0.5 \mathrm{~m}$ average amplitude). This area consists of flooded forests and semi-deciduous forests, and the soil is clayey, rich in sediment. The flood time varies from between two to three months a year in the evaluated areas, being longer in A 3 and shorter in A1. In all three areas selected we found high density of $V$. divergens in monodominant formations, locally called "cambarazais".

In each one of the areas (A1, A2 and A 3) five individuals of $V$. divergens with similar characteristics as to diameter at breast height, height, distribution and vigor of the plant were randomly selected, totaling fifteen selected copies. The selected specimens were at least 10 meters distant one from the other. During the receding water period, three of five individuals selected in the A3 area were inaccessible due to the volume of mud and sediment on the ground, sampling not being possible.

\section{COLLECTION OFPLANT MATERIAL}

After the selection, the sampling of the $V$. divergens leaves was carried out using a trimmer, between September 2012 to June 2013, covering the four seasonal periods of the region (Nunes-da-Cunha and Junk 2000; Alho, 2008). Sampling during the dry period occurred in September 2012, during the rising water in December 2012, in high water in March 2013 and the collection on the receding water season in June 2013. For each plant about $5 \mathrm{~kg}$ of leaves were obtained for each seasonal period. These leaves, after being collected were placed in plastic bags for transport to the Quality Control Laboratory of the Federal University of Mato Grosso - Sinop University Campus. Screening was performed in the laboratory and damaged leaves or leaves with a presence of insects (galling insects) and fungi were discarded. 


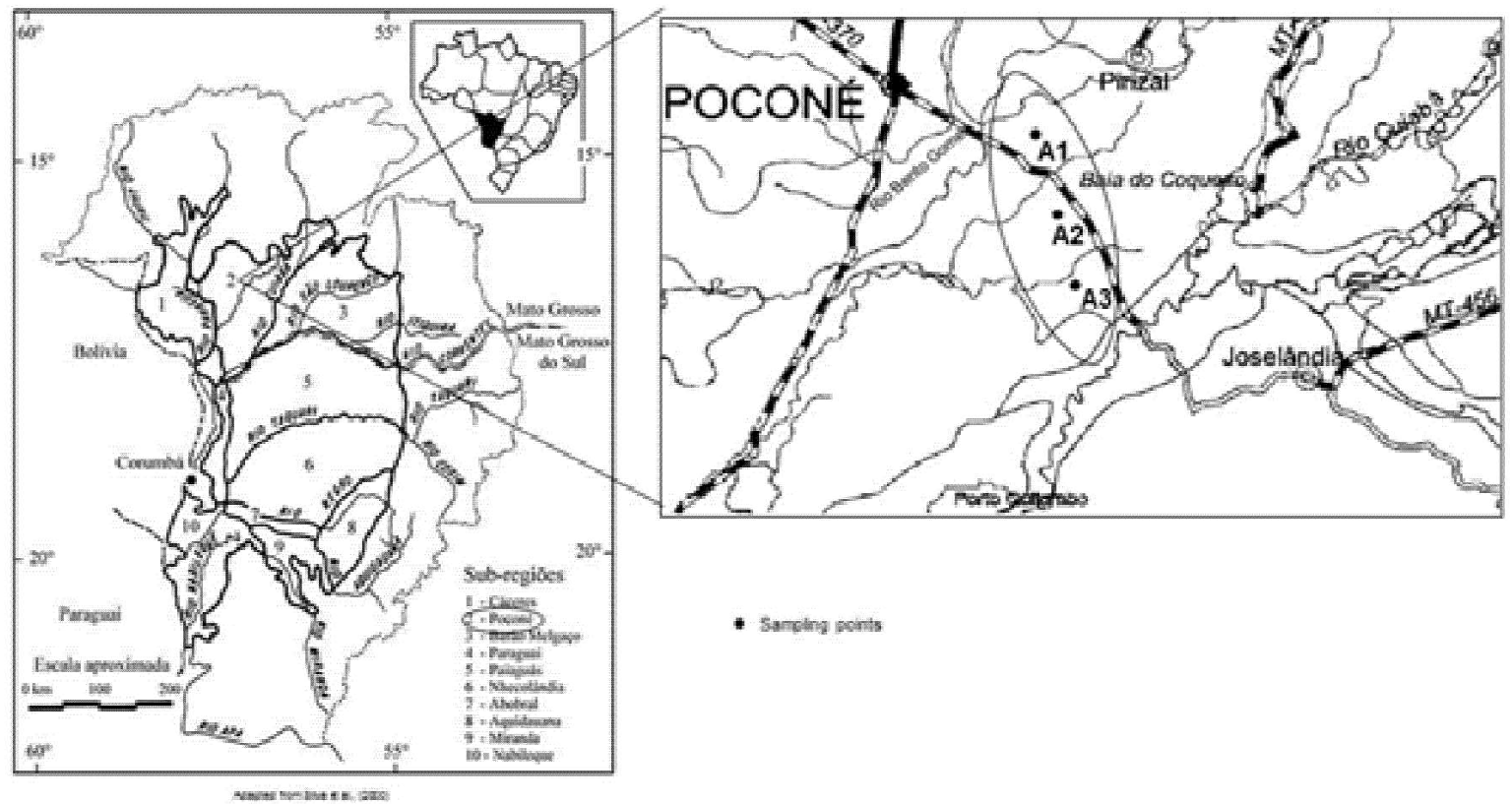

Figure 1 - Localization of the study area, indicating A1, A2 and A3, in the Pantanal of Mato Grosso, Brazil. Figura 1 -Localização da área de estudo, indicando A1, A2 e A3, no Pantanal de Mato Grosso, Brasil.

The leaves were differentiated in relation to plant phenology over the seasonal periods and classified as (i) young leaves, corresponding to the sampling of the dry period, (ii) fully expanded leaves sampled during the rising water, (iii) old leaves obtained in high water season, and (iv) senescence leaves collected during receding water level. The botanical identification was carried out in the Northern Mato Grosso Herbarium Center(CNMT) of the Federal University of Mato Grosso, Sinop University Campus and the voucher specimen deposited under the registration number 4790.

\section{EXTRACT PREPARATIONAND DETERMINATION OFTOTALPHENOLS}

The leaves were dried in an oven with forced air circulation for one week at a temperature of $40^{\circ} \mathrm{C}$. After this period they were ground in a knife mill, sieved through a sieve and subjected to extraction by soaking with ethanol: water (70:30) for seven days. After this period the solvent was evaporated in a rotary evaporator, obtaining the dry extracts.

The determination of total phenol content was carried out by means of spectrophotometry in the visible region, using the adapted Folin-Ciocalteu method (Jayaprakasha et al., 2001). Water, the Folin-Ciocalteu reagent and sodium carbonate solution - $\mathrm{NA}_{2} \mathrm{CO}_{3}(7.5 \%)$, were added to the methanolic extract solutions. The mixture was allowed to rest or stand protected from light for one hour and the absorbance was measured at $750 \mathrm{~nm}$. To elaborate the calibration curve gallic acid was used at concentrations of 10 to $50 \mu \mathrm{g} / \mathrm{mL}$ and total phenols values were expressed as equivalent to gallic acid (mg of gallic acid per g extract). The test was carried out in triplicate for each rated specimen, with the average phenol content obtained in the period being considered for statistical analysis.

The total phenolic content (TPh) was determined by interpolating the absorbance of the samples against a calibration curve constructed with standard of gallic acid (10 to $50 \mathrm{ig} / \mathrm{mL}$ ), expressed as $\mathrm{mg}$ of GAE (gallic acid equivalents) per $g$ extract. The equation of the gallic acid calibration curve was $\mathrm{Y}=0.0071 \mathrm{X}+0.1342$, where $\mathrm{X}$ is the concentration of gallic acid, $\mathrm{Y}$ is the absorbance value at $750 \mathrm{~nm}$, and presented the correlation coefficient $\mathrm{R}=0.999$. The results are expressed as $\mathrm{mg}$ of GAE per g extract.

Revista Árvore. 2017;41(3):e410316 


\section{STATISTICALANALYSIS}

The Variance Analysis (ANOVA) was used to verify how the average concentration of total phenols in $V$. divergens leaves varied according to the seasonal periods (dry season, rising water, high water and receding water), and in relation to areas which received different intensities of flooding (A1, A2, and A3), as well as between the seasonal periods within the same area. The ShapiroWilk test was used to analyze data normality. To identify significant differences the Tukey test was applied. All analyzes were carried out using the $\mathrm{R}$ version 3.0.3 program (R Core Team, 2014).

\section{RESULTS}

The receding water was the period which had the highest mean concentration of total phenols (131.10 \pm 34.89 to $230.94 \pm 122.85 \mathrm{mg}$ of GAE/g of extract), followed by the high water $(49.32 \pm 0.12$ to $87.03 \pm$ $20.81 \mathrm{mg}$ of GAE/g of extract) and rising water (39.67 \pm 19.85 to $54.57 \pm 33.00 \mathrm{mg}$ of GAE/g of extract). The lowest mean concentration was recorded for the dry season $(25.05 \pm 4.60$ to $27.99 \pm 3.77 \mathrm{mg}$ of GAE/g of extract) (Table 1; Figure 2).

Throughout the seasonal periods there was significant difference in the concentration of total phenols independent of the areas analyzed (ANOVA: F 3.46; $p<0.01)$. The receding water period was different from the others (dry $=$ Tukey, $p<0.01$; rising $=$ Tukey, $p<0.01$; and high water period $=$ Tukey, $p<0.01$ ). The comparison of the total phenols concentration between the three areas evaluated did not show significant differences (ANOVA: $F 1.48 ; p=0.13$ ). Area 1 showed variation between 28 and $230 \mathrm{mg}$ GAE/g of extract over seasonal periods, while area 2 ranged from 27 to $215 \mathrm{mg}$ of GAE/ $\mathrm{g}$ of extract and area 3 from 25 to $131 \mathrm{mg}$ of GAE/g extract (Table 1; Figure 2).
Although no significant variation between the three areas was obtained, the concentration of phenolic compounds in the $V$. divergens leaves ranged along seasonal periods within the same area. For area 1 (ANOVA: $F 3.16 ; p<0.01$ ), the receding water differentiated itself from the other periods (dry $=$ Tukey, $p<0.01$; rising $=$ Tukey, $p<0.01$; high water $=$ Tukey, $p<0.01)$. The same result was obtained for area 3 (ANOVA: $F 3.10$; $p<0.01)(\mathrm{dry}=$ Tukey, $p<0.01$; rising $=$ Tukey, $p<0.01$; and high water $=$ Tukey, $p=0.01$ ). In area 2 (ANOVA: $F 3.12 ; p=0.03$ ), the receding water periods took out only in relation to the dry season (Tukey, $\mathrm{p}<0.04$ ).

\section{DISCUSSION}

Plant and animal species that inhabit wetland ecosystems have over evolutionary time developed adaptation or survival strategies that allowed for their development in these habitats (Adis, 1997; Nunesda-Cunha and Junk, 2004; Alho, 2008; Battirola et al., 2009; Marques et al., 2014).

The plants adopt, in addition to morphological and physiological adaptations, other phenological strategies that allow synchronization of their reproductive phenophases, seed dispersal, and exchange of foliage to the environmental conditions of each seasonal period. Vochysia divergens presents this synchronization timing with distribution of its phenophases along seasonal periods with specific phenological characteristics for dry (late stages of flowering, early stages of fruiting and young leaves), rising water (fruit fall, fully expanded leaves), high water level (old leaves, end of fruiting), and receding water level (senescent leaves and beginning of flowering) (Nunes-da-Cunha and Junk, 2000, 2004). Dalmolin et al. (2015) found that the dry season was a key trigger for leaf abscission and leaf and branch emergence in $V$. divergens. Leaf emergence reached two peaks, the first one during the

Table 1 - Average concentration and standard deviation of total phenols (mg GAE/g of extract) extracted from $V$. divergens leaves in the periods of dry, rising water, high water and receding water in the three areas (A1, A2 e A3) with low, intermediary and high levels of inundation, respectively, in the Pantanal of Mato Grosso, Brazil.

Tabela 1 - Concentração média e desvio padrão de fenóis totais ( $m g$ de EAG/g de extrato) extraídos das folhas de V. divergens nos periodos de seca, enchente, cheia e vazante em três áreas (A1, A2 e A3) com baixo, intermediário e elevado nivel de inundação, respectivamente, no Pantanal de Mato Grosso, Brasil.

\begin{tabular}{lcccc}
\hline \multicolumn{5}{c}{ Total phenols (mg GAE/g of extract) } \\
\hline $\begin{array}{l}\text { Seasonal } \\
\text { Periods }\end{array}$ & $\begin{array}{c}\text { Phenology of } \\
\text { the leaves }\end{array}$ & A1 & A2 & A3 \\
\hline Dry & Young & $27,99 \pm 3,77$ & $26,55 \pm 8,83$ & $25,05 \pm 4,60$ \\
Rising water & Fully expanded & $43,55 \pm 8,84$ & $54,57 \pm 33,00$ & $39,67 \pm 19,85$ \\
High water & Old & $87,03 \pm 20,81$ & $54,95 \pm 20,27$ & $49,32 \pm 0,12$ \\
\hline Receding water & Senescent & $230,94 \pm 122,85$ & $214,85 \pm 174,61$ & $131,10 \pm 34,89$ \\
\hline
\end{tabular}


Area 1

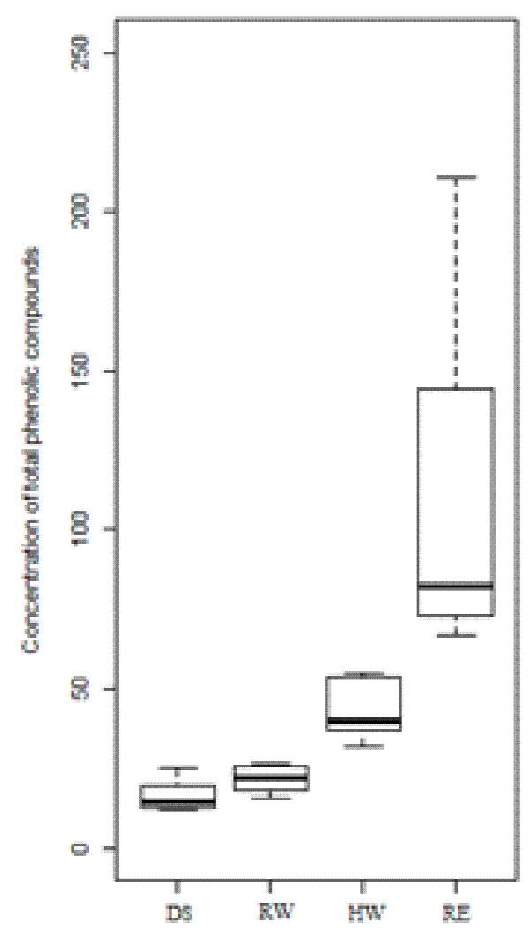

Area 2

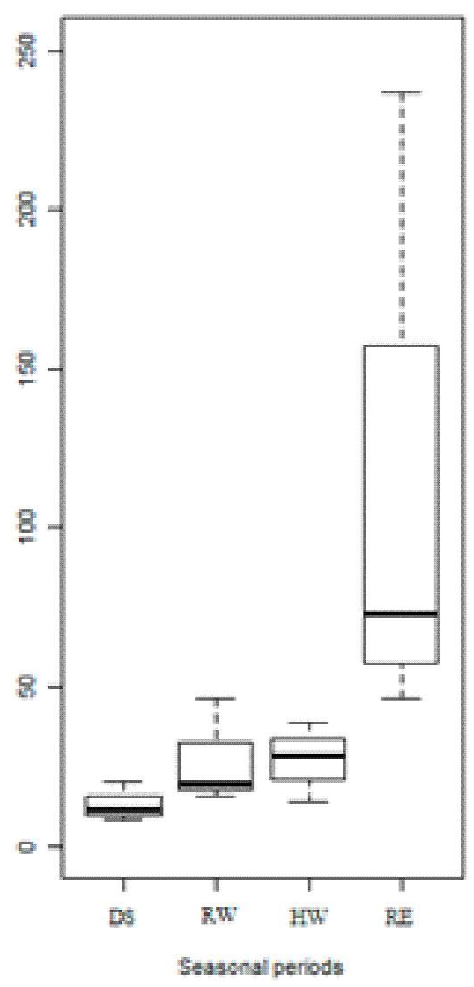

Area 3

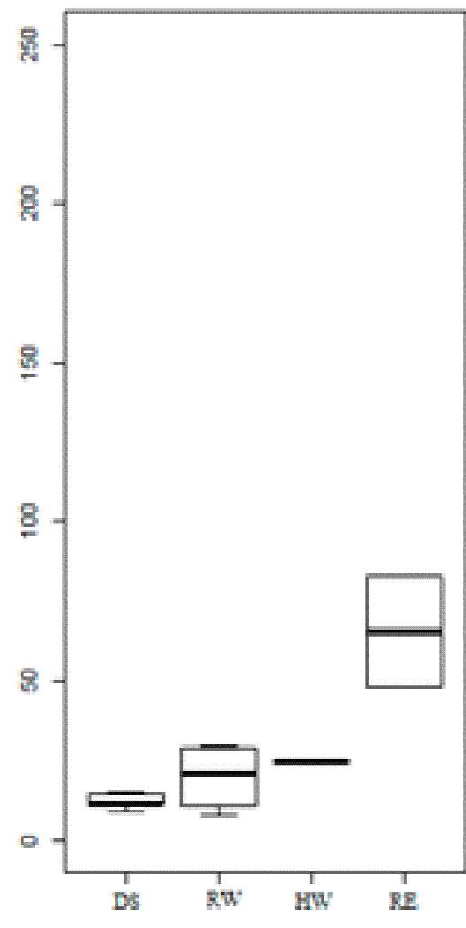

Figure 2 - Concentration of total phenolic compounds extracted from $V$. divergens leaves in the dry season (DS), rising water (RW), high water (HW) and receding water (RE) in areas A1, A2 and A3 in the Pantanal of Mato Grosso, Brazil.

Figura 2 - Concentração de compostos fenólicos totais extraidos das folhas de V. divergens nos períodos de seca (DS), enchente (RW), cheia (HW) e vazante (RE) nas áreas A1, A2 e A3 no Pantanal de Mato Grosso, Brasil.

dry-wet season in October and the second one larger peak during wet-dry season transition in April, and leaf abscission increase during dry-wet transition until February, declined in March and April, and reached peak in May.

Considering the studies carried out on the chemical profile of $V$. divergens, register are only made for research that reports the presence of â-Sitosterol compounds, sericic acid and betulinic acid (Hess et al., 1995), and divergioic acid (Hess and Monache, 1999). In popular medicine tea from the bark and leaves is indicated for influenza, asthma and ulcers (Guarim Neto, 2006; Jesus et al., 2009). Despite these records, one observes a reduced number of studies on the chemical composition of marshland plants, highlighting the need for research related to their phytochemical compounds and their interaction with the dynamics of the ecosystem.

Revista Árvore. 2017;41(3):e410316
In wetlands plants can respond to the flooding process through their chemical defenses, inducing the production of secondary compounds or metabolites in response to water stress (be it shortage or excess) suffered over seasonal periods (Silva et al., 2008). Other factors such as temperature, sunlight, heredity, herbivory and plant development stage, also contribute to changes in the synthesis of these substances (Simões et al., 2007; Silva et al., 2008; Pizzamiglio-Gutierez, 2009).

This relationship between biotic and abiotic factors was observed in the analysis of the variation of the concentration of phenolic compounds in $V$. divergens leaves with the highest concentration in senescent leaves, which occur concurrently at receding water level, followed by the old leaves (high water level), fully expanded leaves (rising water) and young 
(dry season), showing the relationship between phenology of the species and the seasonal periods, with answers in their phytochemical profile, associated with leaf development stages and phenology. Dalmolin et al. (2015) identified high herbivory rate in $V$. divergens leaves during the dry season, with peaks in August, and high values during the transition period between the dry and rainy season. It is observed that the herbivory rate is higher when the $V$. divergens leaves are young and have a lower concentration of phenolic compounds, which could indicate that the synthesis of these compounds is stimulated by the action of the herbivores (Pizzamiglio-Gutierez, 2009) causing the highest concentrations of phenols in the subsequent seasonal periods.

Brahmi et al. (2013) when studying Olea europaea L. (Oleaceae) found that the concentration of phenols is lower on leaves that are still growing and increases when the leaves complete their phenological cycle, a fact, which coincides with the results obtained in this study, in which young leaves presented the lowest concentrations of phenolic compounds.

It is to be noted that the greater part of the synthesis of phenolic compounds is regulated by the phenylalanine ammonia-lyase enzyme, produced from the shikimate pathway, which can be influenced by abiotic factors such as temperature and levels of $\mathrm{CO}_{2}$, as well as by biotic factors such as rate of herbivores and infection by microorganisms (Janas et al., 2000; Assis et al., 2001; Rivero et al., 2001). The study carried out by Castro et al., (2005) with Byrsonima verbascifolia Rich. ex. A. Juss. (Malpighiaceae) showed that, in this species, the increase in phenylalanine ammonia lyase is not related to the phenolic content and total tannins, but the enzyme activity directly responded to environmental variations, registering greater activity in the dry season and the concentration of total phenols remained constant throughout the experiment. These results show that each plant species can get a different physiological response to environmental stimuli.

Formiga et al. (2009) while analyzing total phenolic content in Aspidosperma spruceanum Müll. Arg. (Apocynaceae) observed that the highest total phenol concentrates were recorded during the dry season, and affirms that water stress interferes with the production of metabolites of the shikimate pathway, a factor that explains the variation profile of total phenols in this species. The seasonal water stress, be it either by the high water level (excess water), or drought (water shortage) was considered a factor that interferes with the synthesis of phenolic compounds in $V$. divergens.

The concentration of phenolic compounds was not influenced by different environmental characteristics of the areas under study, showing that there is no direct action or effect of the flood level on the synthesis of these compounds. However, it can be inferred that the flood stimulates the synthesis of phenolic compounds during seasonal periods, as the highest concentration was observed in the receding water period, the period following the high water level when there is a higher level of periodic flooding. The gradual increase in the concentration of phenols during the seasonal periods can be justified by the water stress suffered by the plant (Silva et al., 2008), or as an indirect result of the phenology of the species which presents an increasing concentration of total phenols as the leaves age. Similar results were obtained by Generalic et al., (2012) with Salvia officinalis L. (Lamiaceae), when evaluating phenolic content, antioxidant capacity and antibacterial activity in different periods, and also showed differences throughout the year in phenolic content.

Chehab et al. (2013) obtained results that showed the influence of water stress in the concentration of phenolic compounds in O. europaea, in which the irrigation scheme higher than $75 \%$ obtained the lowest concentration of these compounds. Petridis et al. (2012) evaluated the effect of drought in the phenolic composition of $O$. europaea leaves in four cultivars, and found that the highest concentration was recorded in plants subjected to treatment with the lowest percentage of water saturation. These results are opposite to those obtained for $V$. divergens, but confirm the influence that water stress has in the synthesis of phenolic compounds, where each plant species can respond to stress in different ways and intensities. In a comparative study the on photosynthetic parameters of $V$. divergens and Curatella americana L. (Dilleniaceae) in the Pantanal, Dalmagro et al. (2013) showed that the physiological performance of these species is complex and varied depending on surface hydrology and leaf phenology. Despite showing similar patterns, old leaves of $V$. divergens had a lower and more stable specific leaf area than the young leaves, implying a higher and more consistent allocation of $\mathrm{C}$ to maintain the leaf structure in comparison with C. americana. 


\section{CONCLUSION}

It was concluded that the concentration of total phenolic compounds is influenced by different phenological stages of the $V$. divergens leaves. In this way it can be inferred that the concentration of total phenols increased gradually over the seasonal periods of the Pantanal of Mato Grosso, being indirectly influenced by the flood pulse, and directly by the plant phenology. No difference was observed between the sampling areas, showing that the flood level was not the main factor affecting the concentration of total phenols. As soon as the plant was subjected to a stress situation it increases its defenses, leading to an increase in the production of phenolic compounds in response to environmental stimuli, justifying therefore the presence of higher phenol content in senescent leaves than in old, adult and young leaves.

\section{ACKNOWLEDGEMENTS}

Our thanks the financial support to the Fundação de Amparo à Pesquisa do Estado de Mato Grosso (FAPEMAT PROCESSO 757314/2011) and to the Programa de Pós-Graduação em Ciências Ambientais (PPGCAM/UFMT/Sinop) for the opportunity to carry out this study and. To NEBAM - Núcleo de Estudos da Biodiversidade da Amazônia Mato-grossense and to the Centro de Pesquisas do Pantanal (CPP) for the logistic support. We also thank Msc. Daniel Augusto Batistella and the laboratory colleagues for their cooperation with the collections.

\section{REFERENCES}

Adámoli JO. Pantanal e suas relações fitogeográficas com os cerrados. Discussão sobre o conceito de "Complexo do Pantanal". In: Anais do $32^{\circ}$ Congresso Nacional de Botânica. Sociedade Botânica do Brasil; 1982. p.109-19.

Adis J. Estratégias de sobrevivência de invertebrados terrestres em florestas inundáveis da Amazônia Central: Uma resposta à inundação de longo período. Acta Amazônica. 1997;27:43-54.

Albuquerque UP, Monteiro JM, Araújo EL, Amorim ELC. Taninos: Uma abordagem da química à ecologia. Química Nova. 2005;28:892-6.

Alho CJR. Biodiversity of the Pantanal: Response to seasonal flooding regime and to environmental

Revista Árvore. 2017;41(3):e410316 degradation. Brazilian Journal of Biology. 2008;68:957-66.

Angelo PM, Jorge N. Compostos fenólicos em alimentos - Uma breve revisão. Revista do Instituto Adolfo Lutz. 2007;66:232-40.

Arieira J, Nunes-da-Cunha C. Fitossociologia de uma floresta inundável monodominante de Vochysia divergens Pohl. (Vochysiaceae), no Pantanal Norte, MT, Brasil. Acta Botanica Brasilica. 2006;20:569-80.

Assis J, Maldonado R, Muñoz T, Escribano MI, Merodio C. Effect of high carbon dioxide concentration on PAL activity and phenolic contents in ripening cherimoya fruit. Postharvest Biology and Technology. 2001;23:33-9.

Backman CH. Phenolics-stoting cells: key to programmed cell dead and periderm formation in disease resistence and in general responses in plants? Physiological and Molecular Plant Pathology. 2000;57:101-10.

Battirola LD, Marques MI, Rosado Neto GH, Pinheiro TG, Pinho NGC. Vertical and time distribution of Diplopoda (Arthropoda, Myriapoda) in a monodominant forest in Pantanal of Mato Grosso, Brazil. Zoologia. 2009;26:479-87.

Brahmi F, Mechri B, Dhibi M, Hammami M. Variations in phenolic compounds and antiradical scavenging activity of Olea europaea leaves and fruits extracts collected in two different seasons. Industrial Crops and Products. 2013;49:256-64.

Castro AHF, Alvarenga AA, Soares AM, Young MCM, Purcino AAC. Avaliação sazonal da atividade fenilalanina amonia-liase e dos teores de fenóis e taninos totais em Byrsonima erbascifolia Rich. Ex A. Juss.: Uma espécie medicinal do cerrado. Revista Brasileira de Plantas Medicinais. 2005;7:45-55.

Chaibub BA, Oliveira TB, Fiuza TS, Bara MTF, Tresvenzol LMF, Paula JR. Composição química do óleo essencial e avaliação da atividade antimicrobiana do óleo essencial, extrato etanólico bruto e frações das folhas de Spiranthera odoratissima A. St.-Hil. Revista Brasileira de Plantas Medicinais. 2013;15:225-9. 
Chehab H, Issaou M, Flamini G, Mechri B, Attia F, Luigi CP. et al. Oil quality and aroma composition of "Chemlali" olive trees (Olea europaea L.) under three irrigation regimes. African Journal of Agriculture Research. 2013;8(48):6291-9.

Cobianchi LJA, Silva VC, Dall'oglio EL, Sousa JRPT. Flavonoids from Combretum lanceolatum Pohl. Biochemical Systematics and Ecology. 2013;49:37-8

Dalmagro HJ, Lobo FA, Vourlitis GL, Dalmolin AC, Antunes Jr MZ, Ortíz CER et al. Photosynthetic parameters of two invasive tree species of the Brazilian Pantanal in response to seasonal flooding. Photosynthetica. 2013;51:281-94.

Dalmolin AC, Dalmagro HJ, Lobo FA, Antunes Jr MZ, Ortíz CER, Vourlitis GL. Effects of flooding and shading on growth and gas exchange of Vochysia divergens Pohl (Vochysiaceae) of invasive species in the Brazilian Pantanal. Brazilian Journal of Plant Physiology. 2012;24(2):75-84.

Dalmolin AC, Lobo FA, Vourlitis GL, Silva PR, Dalmagro HJ, Antunes Jr MZ et al. Is the dry season an important driver of phenology and growth for two Brazilian savanna tree species with contrasting leaf habits? Plant Ecology. 2015;216:406-17.

Formiga AT, Gonçalves SJMR, Soares GLG, Isaias RMS. Relações entre o teor de fenóis totais e o ciclo de galhas de Cecidomyiidae em Aspidosperma spruceanum Müll. Arg. (Apocynaceae). Acta Botanica Brasilica. 2009;23:93-9.

Generalic I, Skroza D, Surjak J, Mozina SS, Ljubenkov I, Katalinic' A et al. Seasonal variations of phenolic compounds and biological properties in sage (Salvia officinalis L.). Chemistry and Biodiversity. 2012;9(2):441-57.

Guarim Neto G. O saber tradicional pantaneiro: as plantas medicinais e a educação ambiental. Revista Eletrônica do Mestrado em Educação Ambiental. 2006;17:71-89.

Hagerman AE, Butler LG. Tannins and lignins. In: Rosenthal GA, Berenbaum MR. (Ed). Herbivores; Their interactions with secondary plant, metabolites, the chemical participants. $2^{\text {nd }}$ ed. New York: Academic; 1991. p.355-88.

Hasenack H, Cordeiro JLP, Hofmann GS. O clima da RPPN SESC Pantanal. Porto Alegre: UFRGS; 2003.31p.

Heckman CW. The Pantanal of Poconé. Biota and ecology in the northern section of the world's largest pristine wetland. Dordrecht: Kluwer Academic Publishers; 1998. 622p.

Hess SC, Brum RL, Honda NK, Cruz AB, Moretto E, Cruz RB et al. Antibacterial activity and phytochemical analysis of Vochysia divergens. Journal of Etnopharmacology. 1995;47:97-100.

Hess SC, Monache FD. Divergioic acid, a triterpene from Vochysia divergens. Journal of the Brazilian Chemical Society. 1999;10(2):104-6.

Janas KM, Cvkrová M, Palagiewicz A, Eder J. Alterations in phenyl propanoid cont in soybean roots during low temperature acclimation. Plant Physiology and Biochemistry. 2000;38:587-93.

Jayaprakasha GK, Singh RP, Sakariah KK. Antioxidant activity of grape seed (Vitis vinifera) extracts on peroxidation models in vitro. Food Chemistry. 2001;73:285-90.

Jesus NZT, Lima JCS, Silva RM, Espinosa MM, Martins DT. O. Levantamento etnobotânico de plantas popularmente utilizadas como antiúlceras e antiinlamatórias pela comunidade de Pirizal, Nossa Senhora do Livramento - MT, Brasil. Revista Brasileira de Farmacognosia. 2009;19:130-9.

Junk WJ, Nunes-da-Cunha C, Wantzen KM, Petermann P, Strüssmann C, Marques MI et al. Biodiversity and its conservation in the Pantanal of Mato Grosso, Brazil. Aquatic Sciencie. 2006;68:278-309.

Marques MI, Adis J, Nunes-da-Cunha C, Santos GB. Arthropods biodiversity from the canopy of Vochysia divergens (Vochysiaceae) a forest dominant in the Brazilian Pantanal. Studies on Neotropical Fauna and Environment. 2001;36(3):205-10.

Marques MI, Adis J, Santos GB, Battirola LD. Terrestrial arthropods from tree canopies in the

Revista Árvore. 2017;41(3):e410316 
Pantanal of Mato Grosso, Brazil. Revista Brasileira de Entomologia. 2006;50:257-67.

Marques MI, Santos GB, Battirola LD. Cerambycidae (Insecta, Coleoptera) associados às copas de Vochysia divergens Pohl. (Vochysiaceae) na região norte do Pantanal de Mato Grosso. EntomoBrasilis. 2014;7:159-60.

Nicholson RL, Hammerschmidt R. Phenolic compounds and their role in disease resistence. Annual Review of Phytopathology. 1992;30:369-89.

Nunes-da-Cunha C, Junk WJ. The impact of flooding on distribution of woody plant communities in the Pantanal of Poconé, Mato Grosso, Brazil. In: German-Brazilian Workshop on Neotropical Ecosystems, Archievements and Prospects of Cooperative Research. 2000. p.557-8.

Nunes-da-Cunha C, Junk WJ. Year-to-year changes in water level drive the invasion of Vochysia divergens in Pantanal grasslands. Applied Vegetation Science. 2004;7:103-10.

Nunes-da-Cunha C, Junk WJ. A preliminary classification of habitats of the Pantanal of Mato Grosso and Mato Grosso do Sul, and its relation to national and international wetland classification systems. In: Junk WJ, Nunes-da-Cunha C, Da-Silva CJ, Wantzen KM, editors The Pantanal: Ecology, biodiversity and sustainable management of a large neotropical seasonal wetland. Sofia, Moscow: Pensoft Publishers; 2011. p.127-41.

Petridis A, Therios I, Samouris G, Koundouras S, Giannakoula A. Effect of water deficit on leaf phenolic composition, gas exchange, oxidative damage and antioxidant activity of four Greek olive (Olea europaea L.) cultivars. Plant Physiology and Biochemistry. 2012;60:1-11.

Pinto AC, Silva DHS, Bolzani VS, Lopes NP, Epifânio RA. Produtos naturais: Atualidade, desafios e perspectivas. Química Nova. 2002;25:45-61.

Pizzamiglio-Gutierez MAP. Interações inseto-planta. In: Panizzi AR, Parra JRP organizadores. Bioecologia e nutrição de insetos: base para o manejo integrado de pragas. Brasília: Embrapa; 2009. p.211-39.

Pott A, Pott VJ. Plantas do Pantanal. Centro de Pesquisa Agropecuária do Pantanal; Corumbá:
1994. 320p.

R Core Team. R. A language and environment for statistical computing. Viena: R Foundation for Statistical Computing; 2014. URL Http://www.Rproject.org/.

Rivero RM, Ruiz JM, Garcia PC, Lopes Lefebre LR, Sánchez E, Romero L. Resistance to cold and heat stress: accumulation of phenolic compounds in tomato and watermelon plants. Plant Science. 2001;160:315-21.

Roginsky V, Lissi E. A. Review of methods to determine chain-breaking antioxidant activity in food. Food Chemistry. 2005;92:235-54.

Santos AS, Nunes-da-Cunha C, Tomás W, Abreu UGP, Arieira J. Plantas invasoras no Pantanal: Como entender o problema e soluções de manejo por meio de diagnóstico participativo. Corumbá: Embrapa Pantanal; 2006.

Shahidi F, Naczk M. Food phenolics: sources, chemistry, effects and aplications. Lancaster: Technomic; 1995. 331p.

Silva MP, Mauro R, Mourão G, Coutinho M. Distribuição e quantificação de classes de vegetação do Pantanal através de levantamento aéreo. Brazilian Journal of Botany. 2000;23(2):143-52.

Silva RA, Reis VM, Baldani JIE, Olivares FL. Defesas de plantas contra o ataque de fitopatógenos. Rio de Janeiro: Embrapa Agrobiologia; 2008. 49p. (Documento, 250).

Simões CMO, Schenkley EP, Gosmann G, DeMello JCP, Mentz LA, Petrovick PR.

Farmacognosia: da planta ao medicamento. $6^{\mathrm{a}}$ ed. Porto Alegre: UFRGS; 2007. 1102p.

Sousa CMM, Rocha e Silva H, Vieira Jr G, Ayres MCC, Costa CLS, Araújo DS et al. Fenóis totais e atividade antioxidante de cinco plantas medicinais. Química Nova. 2007;30:351-5.

Trevisan TC, Silva EA, Dall'Oglio EL, Silva LE, Velozo ES, Vieira PC, et al. New quinolizidine and diaza-adamantane alkaloids from Acosmium dasycarpum (Vog.) Yakovlev Fabaceae. Tetrahedron Letters. 2008;49:6289-92.

Revista Árvore. 2017;41(3):e410316 